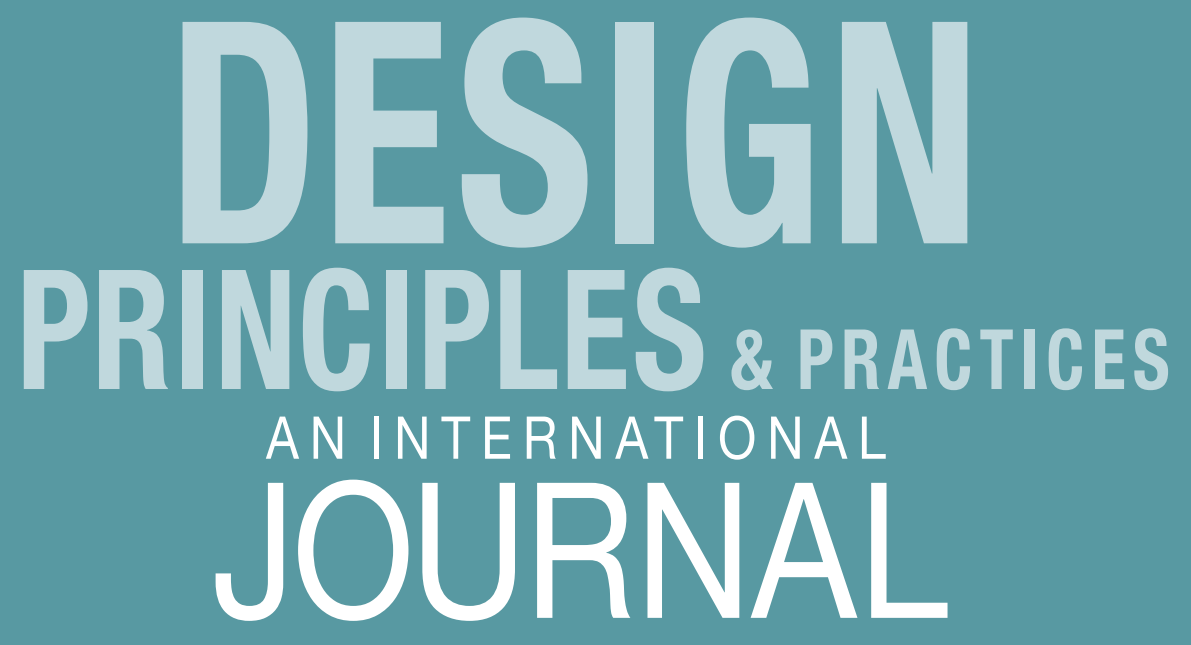

Volume 5, Number 3

A Set of Nine Principles for Distributed-Design Information Storing

Hilary Grierson 
DESIGN PRINCIPLES AND PRACTICES: AN INTERNATIONAL JOURNAL http://www.Design-Journal.com

First published in 2011 in Champaign, Illinois, USA

by Common Ground Publishing LLC

www.CommonGroundPublishing.com

ISSN: $1833-1874$

(C) 2011 (individual papers), the author(s)

(c) 2011 (selection and editorial matter) Common Ground

All rights reserved. Apart from fair dealing for the purposes of study, research, criticism or review as permitted under the applicable copyright legislation, no part of this work may be reproduced by any process without written permission from the publisher. For permissions and other inquiries, please contact

<cg-support@commongroundpublishing.com>.

DESIGN PRINCIPLES AND PRACTICES: AN INTERNATIONAL JOURNAL is peerreviewed, supported by rigorous processes of criterion-referenced article ranking and qualitative commentary, ensuring that only intellectual work of the greatest substance and highest significance is published.

Typeset in Common Ground Markup Language using CGPublisher multichannel typesetting system

http://www.commongroundpublishing.com/software/ 


\title{
A Set of Nine Principles for Distributed-Design Information Storing
}

\author{
Hilary Grierson, The University of Strathclyde, UK
}

\begin{abstract}
The issues of distributed working are many, with problems relating to information access and information acquisition the most common (Crabtree et al., 1997). Keeping track of project and team information is becoming more complex as design is increasingly being carried out collaboratively by geographically dispersed design teams across different time zones. The literature notes that little prescription or guidance exists on information management for designers (Culley et al., 1999) and Hicks (2007) highlights a relative lack of overall principles for improving information management. Additionally, evidence from earlier studies by the author into 'How information is stored in distributed design project work' reinforces the need for guidance, particularly in a distributed context (Grierson, 2008). Distributed information collections were found to be unorganised, contained unclear information and lacked context. Storing and sharing of distributed information was often time consuming and the tools awkward to use. This can lead to poor project progress and can impact directly on the quality and success of project outcomes (Grierson et al., 2004, 2006). This paper seeks to address these issues by presenting the development, implementation and evaluation of a set of Principles and a Framework to support distributed design information storing in the context of a Global Design class. Through both quantitative and qualitative evaluation methods the Principles were found to help in a number of ways - with the easy access of information; the structuring and organising of information; the creation of an information strategy; the making of information clear and concise; the supporting of documentation during project work; and the strengthening of team work; all helping teams to work towards project outcomes.
\end{abstract}

Keywords: Distributed Design, Global Design, Information Management, Project Information Storing, Principles, Framework

\section{Introduction}

$\mathrm{W}$

ITH THE INCREASING globalisation of new product development and a move towards a knowledge-based economy globally distributed collaborations are becoming commonplace in industrialised organisations (Hinds \& Mortensen, 2005). In global environments skills in distributed information management are becoming increasingly important both because of the quantity of information available and because of the ready availability of IT tools to support information management. The literature however, notes that little prescription or guidance exists on information management for designers (Culley et al., 1999); and, more recently Hicks (2007) highlights a relative lack of overall principles for improving information management. Evidence from earlier studies in design education by the author into 'How information is stored in distributed-design project work' reinforces the need for guidance (Grierson, 2008). Student distributed information collections were found to be unorganised, contained unclear information and lacked context. Storing and sharing of distributed information was often time consuming and the

Design Principles and Practices: An International Journal 
tools awkward to use. This can lead to poor project progress and can impact directly on the quality and success of project outcomes (Grierson et al., 2004, 2006).

Additionally, with developments in ICT, students in Higher Education will be expected to possess more advanced skills in sourcing, managing and sharing vast quantities of digital information (Holden, 2003). There is a need to prepare students to work in this international and global context. This paper seeks to address the issues noted above by outlining the development of a set of Principles and a Framework to support distributed-design information storing (d-DIS) (see Grierson \& Ion, 2009 for expanded development) and focusing on their implementation and evaluation in the context of a Global Design Project. The paper illustrates the use of the Principles by students in distributed-design project work however the Principles can be used equally successfully by educators to support the design of distributed project work in classes. The Principles could also be used in industry to improve the information storing practices of those engaged in global team work.

\section{Context for Research Work}

The research took place in the Global Design Class, a $5^{\text {th }}$ year class offered to product design engineering students at the Department of Design, Manufacture and Engineering Management (DMEM) at the University of Strathclyde, Glasgow, U.K., over a period of 4 years. The class gives students hands-on experience of distributed-design with global partners in a Global Design Project, using different collaborative tools including shared workspaces, information storing technologies, video and desktop conferencing. Project tasks were kept simple, e.g. the design of a coffee cup holder and a water station, allowing students to focus on the experience of information exchange, communication and collaboration. Teams comprised 2-3 product design engineering UK students and 2-3 global partners from Stanford University, USA (mechanical engineers) or the Faculty of Design at the Swinburne University of Technology, Australia (product design engineers) or the Department of Industrial \& Manufacturing Engineering at the University of Malta (mechanical engineers). Duration of the various projects was three weeks.

\section{Research Methodology and Data Collection \& Analysis Methods used}

Blessing et al.'s Descriptive/Prescriptive Design Research Methodology (Blessing et al., 1998) was used to add rigour through its formal and systematic approach. It is a recognised methodology in the field of engineering design research as it supports the key stages of design research, namely - the understanding of how the design process under examination actually takes place; the design of a method/model/tool (an intervention) to change the process or practice; and the validation of that intervention. The key research questions are -

\section{$R Q 1$. How do students store and share design information and knowledge in distributed- design team-based project work? \\ $R Q 2$. How can students be encouraged and supported to record project work in a distributed-design context?}

Over a period of two years, early case study work (exploring $R Q 1$ ) identified the issues with distributed-design information storing by examining the information stored in team project websites through detailed data/archive content analysis (quantitative). Questionnaires and 
semi-structured interviews (qualitative) supported and validated the findings (Grierson et al., 2006). The case studies informed how distributed-design information storing could be improved through a series of Recommendations (Grierson \& Ion, 2008). The Principles for d-DIS and a Framework were then derived from these Issues and Recommendations and further developed through a series of Principles' Focus Groups with both students and academics (Grierson \& Ion, 2009). The final stage of research involving the validation of the Principles and Framework, through questionnaires and semi-structured interviews in the context of the 2009-2010 Global Design Project, is the focus of this paper.

\section{Rationale for Principles}

A Principle is basic truth or law or assumption; a generalisation that is accepted as true and can be used as a basis for reasoning or conduct (Webster's Dictionary). Principles have been adopted for a number of reasons. Firstly, they are derived from both the literature and evidence-based research and as such should help guide and inform good practice. They have been used widely in education as a method of support and guidance (Nicol \& McfarlaneDick, 2006). Work by others in Higher Education has shown Principles to be an effective tool to support good practice and to engage and empower students (Chickering \& Gamson, 1991; Nicol, 2007). Secondly, they have a broad relevance and flexibility and are capable of implementation in many ways, suiting a wide range of applications. As such they can be used by students to improve and develop good practice in distributed-design information storing in a wide range of class and project activities, and by staff when designing distributed class activities. Thirdly, principles should be defined independently with minimal overlap. This helps support the factors impacting on distributed-design information storing. Fourthly, their effectiveness should be greater when more principles are operational. And finally, Principles are a topical way of effecting change within the field of engineering design, for example the developing 11 Principles for the Through-Life Management of Engineering Information (McMahon et al., 2009).

\section{Background to the Development of the Principles and Framework}

The Principles evolved from a need identified in the literature; an existing gap in the provision of guidance on engineering information management (Culley et al., 1999; Hicks, 2007), in particular information storing, and from the Issues discovered and the Recommendations made in empirical research Case Studies (Grierson, 2009).

From an initial 246 findings and issues across 6 Case Studies, 29 key Recommendations were identified for improving distributed-design information storing. These had to be reduced to smaller more manageable groups under themes which would form the basis for potential Principles. Coding and clustering (a visual and iterative research method used to inductively form categories through iterative sorting (Miles \& Huberman, 1994)) were used to further refine the Recommendations into themes for the Principles. See Figure 1. 


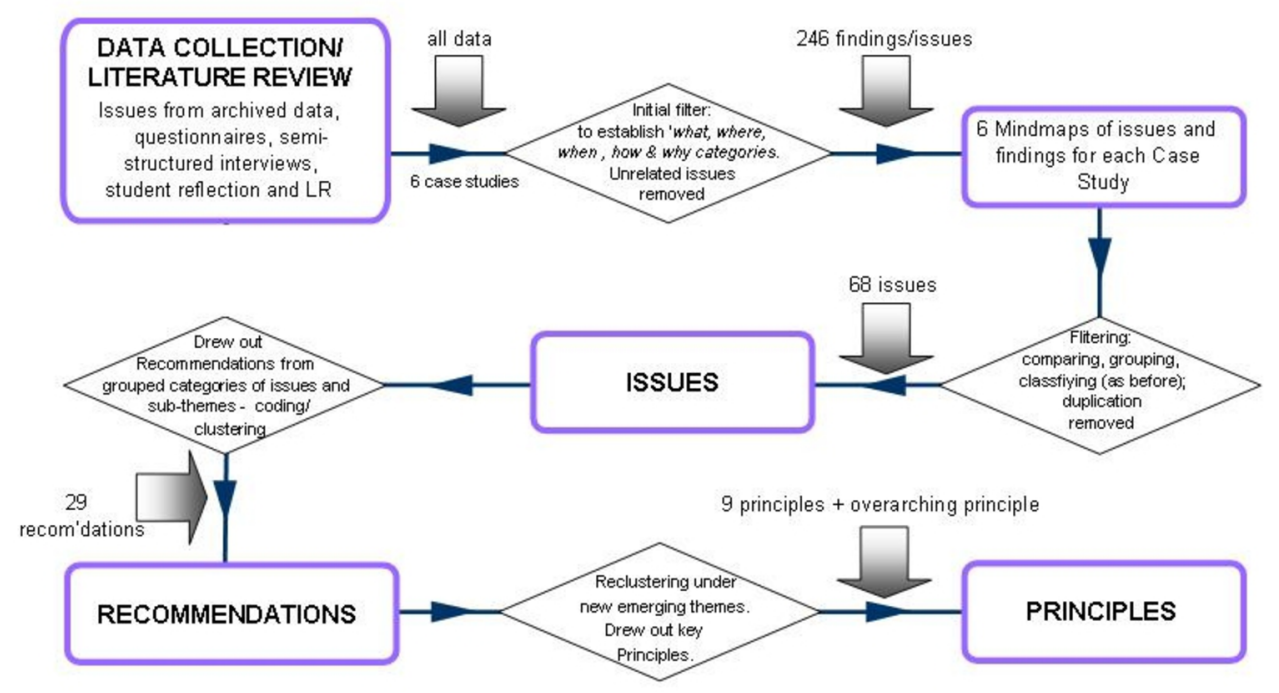

Figure 1: Schematic Representation of Analysis Process (Adapted from Hicks et al., 2006)

Following several versions of the Principles, they were further developed through focus groups. Initial feedback was positive: students, academics and researchers felt their implementation would be very useful and expressed a strong need for a set of guiding Principles for d-DIS. They would help reduce the frustration and confusion often associated with distributed project work, e.g. information stored in several places; ad hoc information lacking in organisation and structure; lack of planning and strategy; lost and incomplete information; lack of context; poor communication; unable to find information, etc. Students reported that implementing the Principles would help them to manage and share project resources better and support better collaboration and allow them to focus more on the design challenge. Academics were in favour of the use of the Principles as their implementation would encourage the creation of valuable archives which could then support project reflection and enhance opportunities for learning. Implementation would promote good practice in distributed-design information storing and better prepare students for industry and employment in the global market. Table 1 presents the final set of Principles.

The Principles can be mapped to a Framework; see Figure 2. Referring to this figure, the Overarching Principle (one of strategy creation) and the Principle of System Support emphasise the creation of rules and familiarisation with chosen tools, before a project start.

The Principles of Information Type; Quantity \& Size; and Context \& Clarity, indicate the need for an information-centred core to project work which includes adequate quantities of both formal information of appropriate content and media type, and informal information to add richness and understanding. The author's previous work defines this core as a Project Memory (Grierson et al., 2006). The concept of project memories “ ... can be defined as lessons and experiences from projects, or as project definition, activities, history and results. It should be a living and active store not static. " (Bannon \& Kuutti, 1999) It provides a central repository and access point for documents, supporting collaboration and distributed communication. 
Table 1: The 9 Principles Distributed-Design Information Storing-final Version

\begin{tabular}{|l|l|}
\hline Overarching Principle & $\begin{array}{l}\text { Develop a distributed team project information storing } \\
\text { strategy early on in distributed project work. }\end{array}$ \\
\hline $\begin{array}{l}\text { Principle of System } \\
\text { Support }\end{array}$ & Select tool(s) and familiarise with use before project start. \\
\hline $\begin{array}{l}\text { Principle of } \\
\text { Information Type }\end{array}$ & $\begin{array}{l}\text { Store an appropriate range of information types: content } \\
\text { (formal and informal), state, media and format, relevant to } \\
\text { project. }\end{array}$ \\
\hline $\begin{array}{l}\text { Principle of Quantity \& } \\
\text { Size }\end{array}$ & $\begin{array}{l}\text { Store an appropriate amount of information relative to project } \\
\text { task and time. }\end{array}$ \\
\hline $\begin{array}{l}\text { Principle of Context \& } \\
\text { Clarity }\end{array}$ & $\begin{array}{l}\text { Store informal information to add shared meaning and under- } \\
\text { standing to formal information in a distributed situation. }\end{array}$ \\
\hline Principle of Structure & Structure and organise distributed design information. \\
\hline $\begin{array}{l}\text { Principle of Location \& } \\
\text { Retrieval }\end{array}$ & Be aware of where distributed design information lies. \\
\hline $\begin{array}{l}\text { Principle of } \\
\text { Consistency }\end{array}$ & $\begin{array}{l}\text { Store distributed design information consistently throughout } \\
\text { project by all members of distributed team. }\end{array}$ \\
\hline $\begin{array}{l}\text { Principle of Interaction } \\
\& \text { Reflection }\end{array}$ & $\begin{array}{l}\text { Interact with and reflect on stored distributed design information } \\
\text { throughout the project. }\end{array}$ \\
\hline Principle of Memory & $\begin{array}{l}\text { Record and communicate a comprehensive memory of project } \\
\text { problems, processes, rationale and outcomes. }\end{array}$ \\
\hline
\end{tabular}




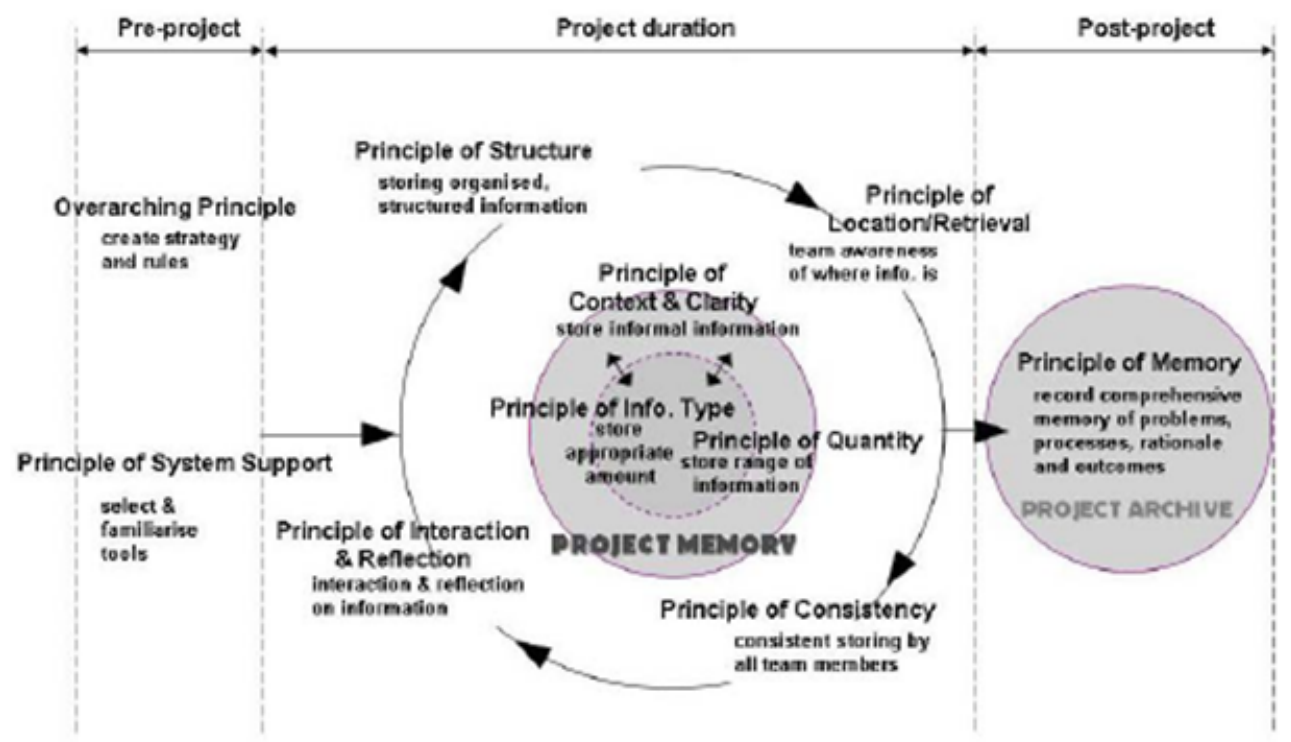

Figure 2: The distributed-Design Information Storing Framework-final Version

The circular arrows around the Project Memory indicate that the Principles of Structure; Location \& Retrieval; Consistency; and, Interaction \& Reflection, should be continually applied throughout distributed project work. Distributed-design information should be organised, comprehensive and unambiguous. It should be stored regularly by all team members who know where to store information and are subsequently aware of where to find project information. Stored information should be reflected upon and interacted with throughout the project rather than at key stages or simply at the end. Schon (1983) identifies the importance of reflection for those working in professional practice; and Kolb (1984) shows that learning can be enhanced when it is organised around cycles of learning activity and reflection. Application of the Principles and recognition of the Principle of Memory results in a comprehensive archive of project problems, processes and outcomes useful both during distributed project work and in subsequent learning.

\section{Implementation in a Global Design Project}

The Principles for d-DIS were first used by Product Design Engineering students from Strathclyde (UK) and Swinburne (Australia) Universities on the asynchronous 2009-2010 Global Design Project. The project task was to design a coffee cup holder. Three web-based tools, Google Docs, Wetpaint and Blogger, (all web-based software technologies suitable for storing project information) were selected by teaching staff based on previous student recommendation for their simplicity of use.

The implementation of the Principles was low key. It was anticipated that since the Principles were able to be used with a high degree of flexibility and since the students involved were final year and postgraduate students that a self-managed approach would be taken. Implementation of the Principles in distributed project work included a one-hour long pre- 
project presentation on the issues associated with distributed-design information storing; the derivation and explanation of the Principles and the Framework; examples of past student distributed-design information storing experiences; and general instructions on the use of the Principles. Student teams were instructed to use the Principles early on during project work and to reflect on their team distributed information management from time to time. Swinburne staff gave the same presentation and similar instruction to their students. Hard copies of the Principles and the Framework and a copy of Principles for $d$-DIS Guidance Document (a more expanded document giving further guidance for each Principle) were issued to each side of the global teams for use during distributed project work.

\section{Evaluation of Principles}

\section{Methods used-Questionnaire and Focus Group}

Evaluation methods included the use of a Questionnaire (with open \& closed response questions and survey style questions) and a Focus Group. Both Strathclyde and Swinburne students contributed to the Questionnaire responses; Strathclyde students participated in the Focus Group.

Questionnaires were issued to both sides of all 11 global teams undertaking the 2009-2010 Global Design Project. 7 complete questionnaires were returned from Swinburne students. These made up the evaluation data set along with the 7 questionnaires from their corresponding Strathclyde local sides. Questionnaire responses were validated with f2f (real-time) Strathclyde student interviews and emails to the Swinburne students. The purpose of the Focus Group was to validate and expand upon the findings of the questionnaires; providing further qualitative evidence and rationale to support the quantitative aspects of the questionnaire. The session was recorded on voice recorder and transcribed. Findings were drawn from the questionnaire and the focus group using Coding and Clustering of emerging themes (Miles \& Huberman, 1994).

\section{Findings and Discussion}

\section{When the Principles for d-DIS were used}

Variation on when the Principles were used by the teams was expected. However it was found that the majority of the Principles were considered 'early on', 'mid project' and 'all throughout', i.e. between the 'dotted lines' of Figures 3 and Figure 4. This is to be encouraged in distributed project work. There were some exceptions. Occurrences of 'never' and 'at the end' were low - 11 local sides reported they 'never' considered a Principle and only 2 local sides reported 'at the end' which is reassuring. 


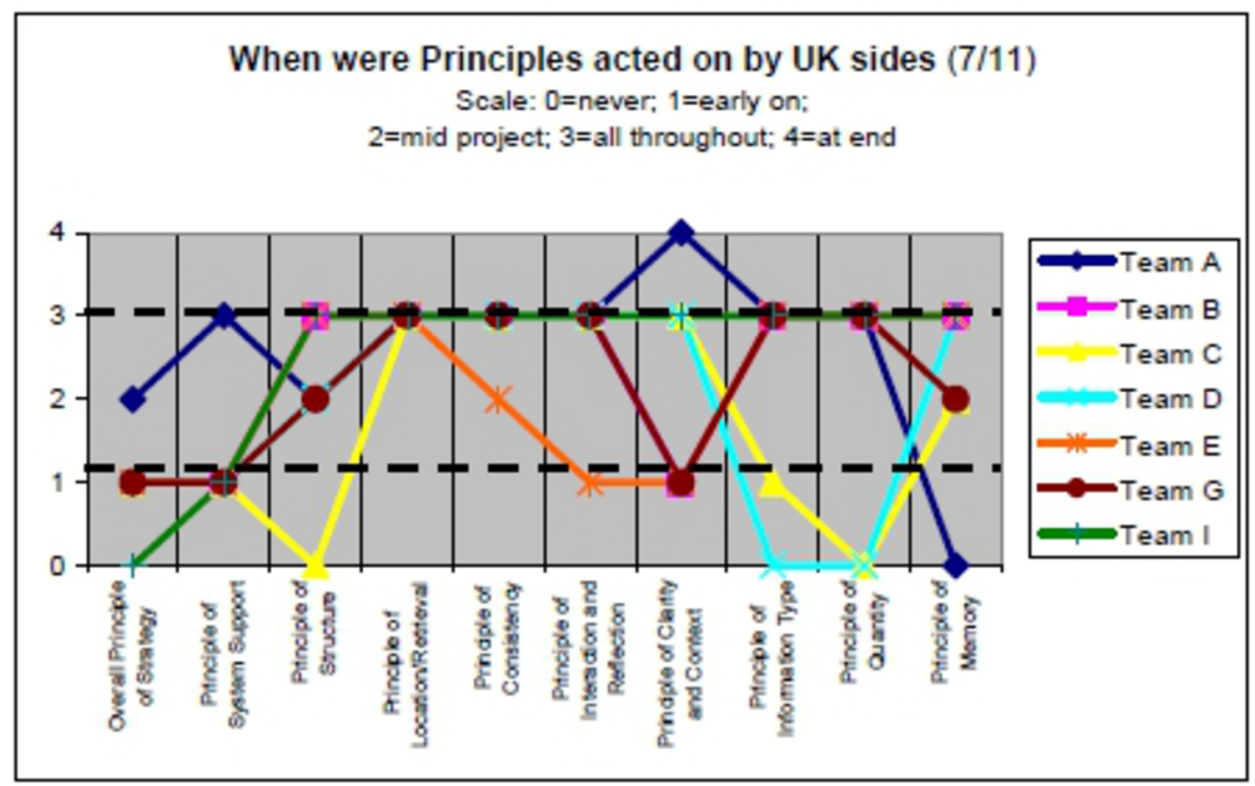

Figure 3: When Principles were acted on by Strathclyde sides

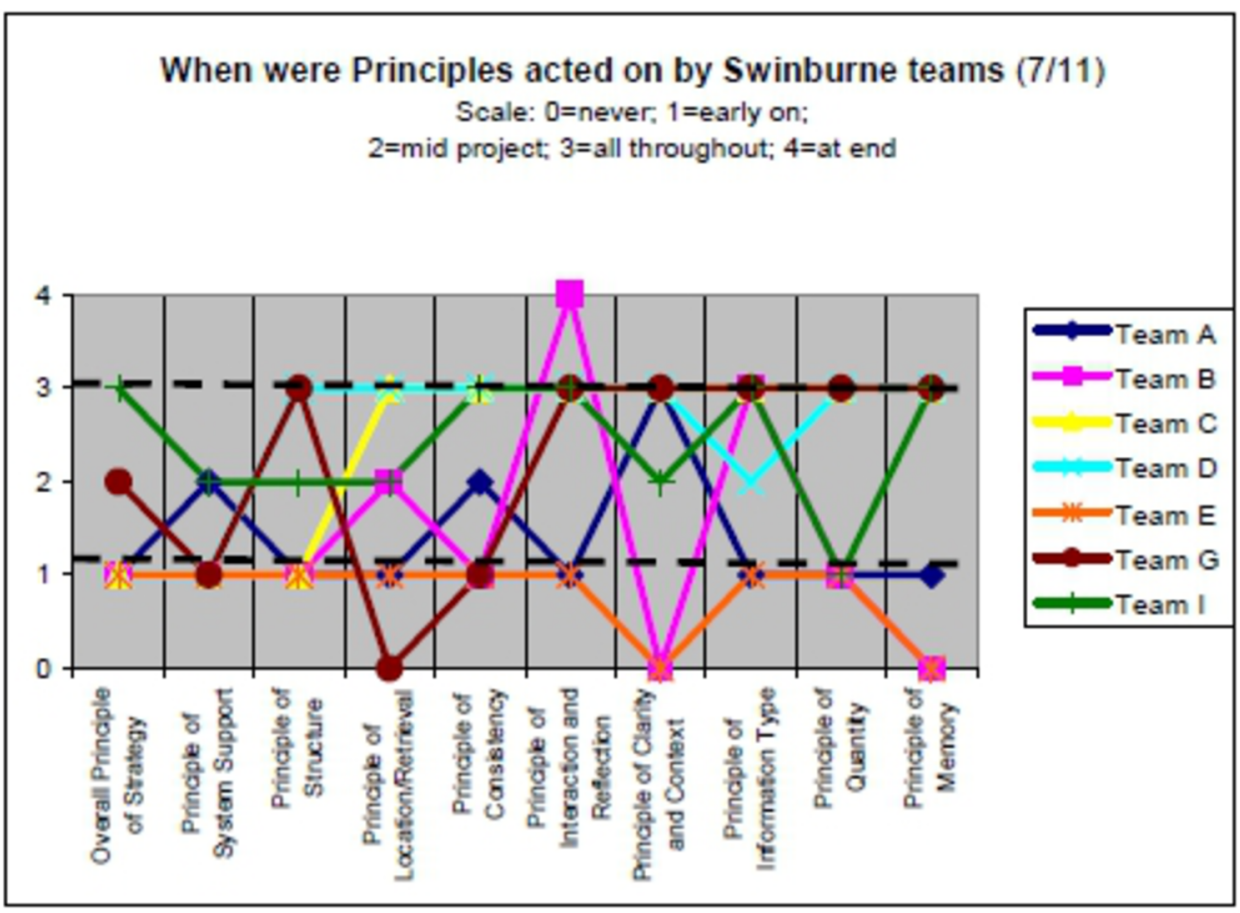

Figure 4: When Principles were acted on by Swinburne sides 
Further examination of the line graphs shows there was also variation across local sides of the global teams, suggesting that the Principles had been used independently by local sides of global teams rather than jointly. This in itself is not problematic however it is important that the Overall Principle of Strategy is developed jointly to help strengthen team cohesion; increase ownership of project information by all and lay out team 'ground rules' early on in distributed project work. Information flows and is shared more effectively when regarded as something belonging to the whole team (Ardichvil et al., 2003). Greater emphasis needs to be placed on the 'joint' aspect of this Principle. In future work the line graph, used to display the results of the use of the Principles in this study, could be used as a visual measure with the aim being to have more 'hits' along the top 'dotted line'.

\section{Consideration of Principles}

\section{The Overall Principle of Strategy}

This Principle was considered to be important to the students - "Absolutely necessary " (Student 3). It was considered by most teams either 'early on ', ' mid project ' or ' all throughout '. Application of this Principle included: development of project plans to include communication, uploading and updating of information (Teams B,C,E); use of various areas of tool(s) to support information storing (Teams A,D,E); and use of a communications tool alongside information storing tool to discuss information (Teams D,E).

\section{The Principle of System Support}

The majority of the sides of teams considered and acted on this Principle 'early on ', with several teams 'linking to' a communications tool to support their information storing tool. This Principle was found to reduce anxiety at the start of a project, “ ... because as it is you have too many unknowns going into a project. " (Student 2)

\section{The Principle of Structure}

Structuring and organising distributed information is key to being able to find it. A variety of methods were used to structure and organise project information (sometimes limited by the simplicity of some of the technologies used), for example, use of different web pages for specific information (Team A,B); storing of information chronologically (Teams C,D,I); creation of hierarchies for sharing information (Team A); and use of folders (Team G).

\section{The Principle of Location \& Retrieval}

Reported considerations in relation to this Principle included - information was more easily located due to notification or communication about the information itself; communication levels needed to be kept high; and the use of a centralised information storing tool helped the awareness of distributed-design information. 


\section{The Principle of Consistency}

Students recognised the need for the consistent and frequent storing of distributed information as important. Consideration of this Principle involved - the regular uploading of information (Teams A,B,C); the appropriate naming of files (Teams A,D); the use of templates (Teams $\mathrm{G}, \mathrm{C}$ ); and the use of consistent file types (Teams E,G).

\section{The Principle of Interaction \& Reflection}

Students applied this Principle, by looking back and discussing stored information in shared project websites, discussion boards, discussion threads, email or blogs. (Teams A,B,C,D,E,I)

\section{The Principle of Context \& Clarity}

Students realised that in distributed-design work greater context was needed (more informal information) to explain the formal documents they stored. Methods used by teams to add context and clarity included - greater informal information in communications (all); the addition of personal information (Teams B, G); and the use of video to explain concepts further (Team C).

\section{The Principle of Information Type}

Students noted they stored a wide range of information carriers - images, pictures, sketches, video, text, CAD work, mind maps, concepts and links. (Teams C,D,E,G,I) File formats included - excel and Word docs, pdfs, PPTs and image files.

\section{The Principle of Quantity \& Size}

With increasing storage space available at decreasing costs there is concern that teams are not evaluating the quality of distributed information on project work (Teams C,D) and simply storing information because they can. Students need to be capable of evaluating information worth in different contexts and reducing information overload.

\section{The Principle of Memory}

This Principle was designed to encourage the storing of a comprehensive picture of project processes and outputs, including the more informal communication. The greatest numbers of sides of teams reported they 'never ' considered this principle. (Strathclyde side of Team A and Swinburne side of Teams E,G) Strathclyde students accredited this to a lack of time on shorter projects and the fact they could remember project problems and processes. In the case of longer projects however, they felt it would prove invaluable.

\section{Effectiveness of Principles as used in Global Design Project}

Local sides of teams responding to the questionnaire were asked to give an 'effectiveness' rating on a scale of 1-5 for each Principle. Effectiveness ratings fell within the range of 3.3 - 4.3; see Table 2. This is a very good result based on the minimum intervention applied. 
Strathclyde-sides tended to score slightly more favourably than the Swinburne sides, but not on all Principles. The author recognises this may have been slightly affected by researcher familiarity.

Table 2: Students' Reporting on the Effectiveness of each Principle

\begin{tabular}{|l|c|c|c|}
\hline $\begin{array}{l}\text { Effectiveness rating } \\
\text { 1 least effective to 5 most effective }\end{array}$ & $\begin{array}{c}\text { Strathclyde } \\
\text { Ratings }\end{array}$ & $\begin{array}{c}\text { Swinburne } \\
\text { Ratings }\end{array}$ & $\begin{array}{c}\text { Combined } \\
\text { (Global) } \\
\text { Ratings }\end{array}$ \\
\hline Overall Principle of Strategy & 3.9 & 4.0 & 3.9 \\
\hline Principle of System Support & 4.0 & 3.7 & 3.9 \\
\hline Principle of Structure & 4.3 & 3.7 & 4.0 \\
\hline Principle of Location \& Retrieval & 4.3 & 3.7 & 4.0 \\
\hline Principle of Consistency & 3.9 & 4.3 & 4.1 \\
\hline Principle of Interaction \& Reflection & 3.9 & 4.0 & 3.9 \\
\hline Principle of Context \& Clarity & 4.0 & 3.3 & 3.6 \\
\hline Principle of Information Type & 3.4 & 3.7 & 3.6 \\
\hline Principle of Quantity & 4.0 & 3.9 & 3.9 \\
\hline Principle of Memory & 4.1 & 3.3 & 3.6 \\
\hline
\end{tabular}

Combined results indicate global teams found the Principles of Consistency, Structure and Location/Retrieval to be the most effective; closely followed by the Principles of System Support, Interaction \& Reflection and Quantity \& Size. The lesser effective results need further discussion: the combined 'effectiveness' rating for the Principle of Context and Clarity and for the Principle of Memory (both 3.6:combined) were affected by a non-return of an 'effectiveness rating' from Swinburne Team B.

Students reported that some of the Principles worked more effectively together and indeed depended on each other. For example, students at the Focus Group suggested that the Principle of Context and Clarity needed to be applied for the Principle of Interaction \& Reflection to be effective. Context at the time has to be captured to make reflection on stored information meaningful and worthwhile.

\section{Impact of Principles on Teams}

Key to the questionnaire was a series of 16 closed statements seeking agreement or disagreement generated from the aims of the Principles, the Principles themselves, and the use of the Principles. For a complete record of responses see Table 3.

The closed statements indicated that teams were very much in agreement with: structuring and organising of project resources $(100 \%)$; knowing where project information was $(100 \%)$; the creation of a strategy or rules ( $93 \%$ ); interaction and reflection on stored project information to support decision making and to progress work (93\%); and, the storing of information being frequent throughout distributed projects (93\%). 
$86 \%$ of responses noted that overall the Principles helped support information storing on the 2009-2010 Global Design project (with 14\% neither agreeing nor disagreeing (na/d)); and that $71 \%$ felt they contributed to a satisfying distributed team experience (with $29 \%$ $\mathrm{na} / \mathrm{d}$ ). This is a positive outcome. In the earlier cases studies (2006-2008 Global Design Projects) teams expressed some level of frustration at points during project work. Surprisingly, whilst the Principles helped support their distributed-design information storing practices, only $57 \%$ of the responses considered their information management skills to be improved $(36 \% \mathrm{na} / \mathrm{d})$.

Overall $71 \%$ of responses agreed $(29 \%$ na/d) that the Principles helped to create a reusable project archive and that distributed project work required a Project Memory. More Strathclyde sides of teams agreed ( $86 \%$ agreeing: $14 \%$ na/d) than Swinburne sides (57\% agreeing: $43 \%$ $\mathrm{na} / \mathrm{d})$. This was due in part to the requirement for the Strathclyde students to produce a reflective report for assessment following project work.

$71 \%$ of responses agreed that informal information benefitted distributed project work (with $22 \% \mathrm{na} / \mathrm{d}$ and only one Swinburne side disagreeing). This is encouraging, that although students in earlier studies found storing informal information difficult and time consuming, the need to add context to distributed work was recognised.

Students did not find the use of the Principles saved time due to the shortness of the project (36\% agreeing; $43 \%$ na/d and $21 \%$ disagreeing). Use of the Principles would be more effective on longer projects for two reasons: more time would be available to implement them or carry out project activities related to them; and the need for a PM would be greater due to a tendency to forget increasingly greater amounts of project information over longer periods of time. 
Table 3: Students' Reporting on the Impact of each Principle

\begin{tabular}{|c|c|c|c|}
\hline $\begin{array}{l}\text { \% agreeing and disagreeing to } 16 \text { structured statements: } \\
\text { Global teams }- \text { Strathclyde }+ \text { Swinburne } \\
\text { ['Strongly agree' and 'agree' merged. 'Strongly disagree' and 'disagree' } \\
\text { merged] }\end{array}$ & 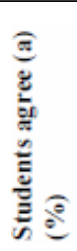 & 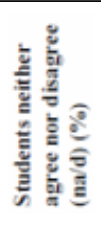 &  \\
\hline Creation of a strategy and rules early on helps distributed team work. & 93 & & 7 \\
\hline $\begin{array}{l}\text { The Principles for distributed-design information storing helped support } \\
\text { information storing in this project. }\end{array}$ & 86 & 14 & \\
\hline $\begin{array}{l}\text { Use of the Principles helped generate a good re-usable project archive } \\
\text { which told a comprehensive story of our project. }\end{array}$ & 71 & 29 & \\
\hline $\begin{array}{l}\text { Interacting with and referring back to stored information helps decision } \\
\text { making and progresses project work. }\end{array}$ & 93 & 7 & \\
\hline Storing informal information benefits distributed project work. & 72 & 21 & 7 \\
\hline $\begin{array}{l}\text { Using and applying the Principles gave us a good understanding of } \\
\text { storing information in distributed project work and improved our in- } \\
\text { formation storing skills. }\end{array}$ & 57 & 36 & 7 \\
\hline $\begin{array}{l}\text { Being familiar with the information storing technologies is not neces- } \\
\text { sary. }\end{array}$ & 42 & 14 & 42 \\
\hline $\begin{array}{l}\text { To maximise the use of project resources stored online you need to } \\
\text { structure and organise information. }\end{array}$ & 100 & & \\
\hline It is not important to know where project information is located. & & & 100 \\
\hline Information should only be stored and shared at milestones or the end. & & 7 & 93 \\
\hline $\begin{array}{l}\text { Distributed-design project work can be carried out without an online } \\
\text { store or 'Project Memory' of project information. }\end{array}$ & & 29 & 71 \\
\hline We are still unsure about what information to store and how much. & & 57 & 43 \\
\hline $\begin{array}{l}\text { Applying the Principles saved time which could be spent on other } \\
\text { project activities. }\end{array}$ & 36 & 43 & 21 \\
\hline $\begin{array}{l}\text { Use of the Principles contributed to a satisfying distributed team-based } \\
\text { project work experience. }\end{array}$ & 71 & 29 & \\
\hline $\begin{array}{l}\text { Our team took full advantage of the Principles - their application, the } \\
\text { checklist, examples, etc. }\end{array}$ & 14 & 57 & 29 \\
\hline $\begin{array}{l}\text { The information, guidance and materials given on the Principles were } \\
\text { sufficient and helpful. }\end{array}$ & 64 & 36 & \\
\hline
\end{tabular}




\section{How the Principles Helped Distributed-Design Information Storing}

At the Focus Group the students returned 51 responses on the how the Principles helped their teams. The responses were categorised and coded; see Table 4.

Table 4: Content Analysis of Activities Supported by Consideration of the Principles

\begin{tabular}{|l|c|c|}
\hline Consideration of Principles helped teams to - & $\begin{array}{c}\text { Category } \\
\text { Coding }\end{array}$ & $\begin{array}{c}\text { Category } \\
\text { Mentions }\end{array}$ \\
\hline Access information easily & A & 7 \\
\hline Structure and organise distributed information & OS & 7 \\
\hline Adopt a Strategic approach to distributed information management & St & 5 \\
\hline Keep information Clear and Concise & CC & 5 \\
\hline Document throughout all stages, be consistent & DT & 4 \\
\hline Realise need to be Familiar with Tools & FT & 3 \\
\hline Strengthen Teamwork and Collaboration & Tm & 3 \\
\hline Think about Usefulness and Value of information & $\mathrm{UV}$ & 3 \\
\hline Realise the Importance of Informal Information to add Context & $\mathrm{C}$ & 3 \\
\hline Work towards a Project Outcome & $\mathrm{PO}$ & 3 \\
\hline Increase Understanding of what they were expected to do & $\mathrm{U}$ & 3 \\
\hline Remember Information (Memory) & $\mathrm{M}$ & 2 \\
\hline Reflect on information & $\mathrm{R}$ & 1 \\
\hline Learn from problems, Lessons Learnt & $\mathrm{LL}$ & 1 \\
\hline Be aware of Security & $\mathrm{S}$ & 1 \\
\hline Total & & 51 \\
\hline
\end{tabular}

The frequency of each category was noted to give some indication of how the Principles supported the students most. Many were reported to help with issues previously identified in the Case Studies which supports the internal validity of the work.

Application of the Principles were most beneficial in helping -

- to access information easily;

- to structure and organise distributed information; (This corroborates with the highest Strathclyde 'effectiveness' ratings returned for the Principles from the Questionnaire, see Table 2.)

- to play a central role in the development of an information strategy; and

- to make information clear and concise.

These corresponded to problematic areas evidenced in the early Case Studies to greater or lesser extents. The Principles were however less instrumental in getting the teams to reflect 
on the information they had stored with only two mentions of 'reflection' and 'lessons learnt'.

\section{Future Use of Principles}

At the Focus Group participants all agreed they would use the Principles for d-DIS in future distributed-design project work, see Table 5. Overall students expected the Principles would be most beneficial in supporting the development of a strategic approach to distributed information management and to retain valuable information. On longer projects they anticipated their implementation would be even more beneficial and would also save time.

Table 5: Content Analysis of Responses to Future Use of Principles

\begin{tabular}{|l|c|c|}
\hline Future Use of Principles & Code & $\begin{array}{c}\text { Number of } \\
\text { responses } \\
\text { mentioning item }\end{array}$ \\
\hline $\begin{array}{l}\text { Adopt a Strategic approach to distributed information manage- } \\
\text { ment }\end{array}$ & $\mathrm{St}$ & 3 \\
\hline Document throughout all stages, not lose information & $\mathrm{DT}$ & 2 \\
\hline Impact on time & $\mathrm{T}$ & 2 \\
\hline Organise and Structure distributed information & OS & 1 \\
\hline Realise need to be Familiar with Tools & $\mathrm{FT}$ & 1 \\
\hline Strengthen Teamwork and Collaboration & $\mathrm{Tm}$ & 1 \\
\hline Remember Information (Memory) & $\mathrm{M}$ & 1 \\
\hline Total & & 11 \\
\hline
\end{tabular}

\section{Conclusions}

Early studies in design education by the author (Grierson et al., 2004, 2006; Grierson 2008) into 'How information is stored in distributed-design project work' identified issues with distributed-design information storing by examining the information stored in team project websites. Student distributed information collections were found to be unorganised and lacked structure; they contained unclear information which often lacked context. Information was often stored in several places, incomplete or even lost. Storing and sharing of distributed information was often time consuming and the tools awkward to use. Students failed to plan or create a strategy leading at times to difficulties in finding distributed information and to poor communication.

This reinforced the need for guidance in distributed-design information storing and the development of a set of Principles and a Framework for information storing to support distributed-design project work.

This paper has presented evidence that a Set of 9 Principles and a Framework for distributed-design information (d-DIS) storing would help students to - 
- develop a distributed-design project information strategy,

- manage and share project resources,

- achieve a shared understanding of the project problem,

- enhance distributed team communication,

- create a rich and meaningful story of project problems, challenges, processes, rationale and outcomes, and

- reflect on project processes, group and individual performance and learning achievements.

For greatest effect, global teams should develop an Overall Strategy which involves considering all the Principles at the start of the project and then applying the 9 Principles for d-DIS 'all throughout'. This supports the management and sharing of distributed information; interaction and reflection with the stored information and improved distributed information storing skills.

Evaluation proved students were in strong agreement that they were in a better position to know how to store project information in a distributed context, having been introduced to the Principles. They noted the Principles for d-DIS would be even more beneficial on longer distributed projects and that the Principles should be enforced to an even greater degree in class. These aspects will be focus for future studies.

\section{References}

Ardichvil, A., Page, V. \& Wentling, T., 2003. Motivation and barriers to participation in virtual knowledge sharing communities of practice. Journal of Knowledge Management, 7(1), pp.6477.

Bannon, L. \& Kuutti, K., 1996. Shifting perspectives on organizational memory: From storage to active remembering. In the Proceedings of The 29th IEEE HICSS, 1996, 3. IEEE Computer Society Press, pp156-167.

Blessing, L.T.M., Chakrabarti, A., Wallace, K.M., 1998. An overview of descriptive studies in relation to a general design research methodology In E., Frankerberger, P., Badke-Schaub, \& H., Birkhofer, (eds.) Designers: The Key to Successful Product Development. Springer, London, pp.42-56.

Chickering, A.W. \& Gamson, Z.F., 1991. Applying the seven principles of good feedback practice in undergraduate education. Jossey-Bass: San Francisco.

Crabtree, R. A., Fox, M.S. \& Baid, N.K., 1997. Case studies of coordination activities and problems in collaborative design. Research in Engineering Design, 9(2), pp.70-84.

Culley, S. J., O. P. Boston and C. A. McMahon, 1999. Suppliers in new product development: Their information and integration. Journal of Engineering Design, 10(1), pp.59-75.

Grierson, H., Nicol, D., Littlejohn, A. \& Wodehouse, A., 2004. Structuring and sharing information resources to support concept development and design learning. In: Proceedings of The Network Learning Conference, 5-7 April, Lancaster University, pp.572-579.

Grierson, H., Ion, W. \& Juster, N., 2006. Project memories: Documentation and much more for global team design. In: Proceedings of The International Engineering and Product Design Education Conference '06, 7-8 September, Salzburg, Austria.

Grierson, H. and Ion, W., 2008. Distributed Design Information \& Knowledge: Storage and Strategy. In: Proceedings of The International Engineering and Product Design Education Conference '06, 4-5 September, Barcelona.

Grierson, H., \& Ion, W.J., 2009. Towards a set of principles for distributed-design information storing. In: Proceedings of The International Conference on Engineering Design, ICED '09. 2427 August. Stanford University, Stanford, C.A., USA. 
Hicks, B. J., Culley, S.J. \& McMahon, C.A., 2006. A study of issues relating to information management across engineering SMEs. International Journal of Information Management, 26 (4), pp. 267-289.

Hicks, B., 2007. Lean information management: Understanding and eliminating waste. International Journal of Information Management, 27(4), pp.233-249.

Hinds, P. \& Mortensen, M., 2005. Understanding conflict in geographically distributed teams: The moderating effects of shared identity, shared context, and spontaneous communication. Organisational Science, 16(3), pp.290-307.

Holden, C., 2003. Learning repositories summit: initial research summary. Advanced Distributed Learning Summit, University of Wisconsin, Madison. Available at: http://www.academiccolab.org/resources/RepositoryPaper.pdf (Accessed 1 July, 2010).

Kolb, D., 1984. Experiential Learning: on the science of learning and development. San Francisco: Jossey-Bass.

McMahon, C.A., Caldwell, N., Darlington, M., Culley, S.J., Giess, M., Clarkson, J., 2009. The development of a set of principles for the through-life management of engineering information. Documentation, Bath, England: University of Bath, (kim40rep007mjd10). Available at: http://opus.bath.ac.uk/16132/1/kim40rep007mjd10.doc (accessed 2 July 2010).

Miles, M.B. \& Huberman, A.M., 1994. Qualitative data analysis: An expanded sourcebook. 2nd ed. London: Sage \& California: Thousand Oaks.

Nicol, D.J. \& Macfarlane-Dick, D., 2006. Formative assessment and self-regulated learning: A model and seven principles of good feedback practice. Studies in Higher Education, 31(2), pp.199218 .

Nicol, D., 2007. Principles of good assessment and feedback: theory and practice. Keynote paper at Assessment design for learner responsibility conference, 29-31 May 2007. Available at: http://www.reap.ac.uk/reap07/Welcome/tabid/72/Default.html (accessed 4 July 2010).

Schon, D., 1983. The Reflective Practitioner. San Francisco: Jossey-Bass.

Webster's Dictionary. Available at: http://www.webster-dictionary.net (accessed 12 December 2010).

\section{About the Author}

\section{Dr. Hilary Grierson}

Hilary Grierson, studied Architecture and Design at the University of Strathclyde, Glasgow, graduating BArch (1984), and MSc in Computer-aided Building Design (1985); and at the Graduate School of Design, Harvard University, MA (1985-86). Currently a Lecturer in Design at the Department of Design Manufacture and Engineering Management at the University of Strathclyde; Lecturing in Engineering Design and Global Design. Research activities include technologies for design education and distributed design; distributed design information management; design and use of digital libraries; distributed creativity. Most recently, worked on the DIDET project (www.didet.ac.uk) with the Center for Design Research at Stanford University, USA, investigating digital libraries for global distributed design education and team working. Published in over 35 journal and conference papers, both national and international. 



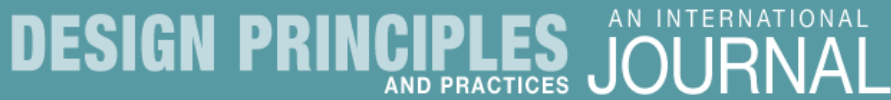

\section{Editors}

Bill Cope, University of Illinois, Urbana-Champaign, USA.

Mary Kalantzis, University of Illinois, Urbana-Champaign, USA.

\section{Editorial Advisory Board}

Genevieve Bell - Intel Corporation, Santa Clara, USA.

Michael Biggs - University of Hertfordshire, Hertfordshire, UK.

Thomas Binder - Royal Danish Academy of Fine Arts, Copenhagen, Denmark.

Jeanette Blomberg - IBM Almaden Research Center, San Jose, USA.

Eva Brandt - Danmark Designskole, Copenhagen, Denmark.

Peter Burrows - RMIT University, Melbourne, Australia.

Monika Büscher - Lancaster University, Lancaster, UK.

Patrick Dillon - Exeter University, Exeter, UK.

Michael Gibson, University of North Texas, Denton, USA.

Loredana Di Lucchio, Sapienza Universita di Roma, Rome, Italy.

Judith Gregory - IIT Institute of Design, Chicago, USA; University of Oslo, Norway.

Clive Holtham - City of London University, London, UK.

Lorenzo Imbesi, Carleton University, Ottawa, Canada.

Hiroshi Ishii - MIT Media Lab, Cambridge, USA.

Gianni Jacucci - University of Trento, Trento, Italy.

Klaus Krippendorff - University of Pennsylvania, Philadelphia, USA.

Terence Love - Curtin University, Perth, Australia.

Bill Lucas, MAYA Fellow, MAYA Design, Inc., Pittsburgh, USA.

Ezio Manzini - Politecnico of Milano, Milan, Italy.

Mario Minichiello, Birmingham Institute of Art and Design, Birmingham, UK.

Julian Orr - Work Practice \& Technology Associates, Pescadero, USA.

Mahendra Patel - Leaf Design, Mumbai, India.

Toni Robertson - University of Technology Sydney, Sydney, Australia.

Terry Rosenberg - Goldsmiths, University of London, London, UK.

Keith Russell - University of Newcastle, Callaghan, Australia.

Liz Sanders - Make Tools, USA.

Maria Cecilia Loschiavo dos Santos - University of São Paulo, São Paulo, Brazil.

Lucy Suchman - Lancaster University, Lancaster, UK.

Ina Wagner - Technical University of Vienna, Vienna, Austria.

Please visit the Journal website at http://www.Design-Journal.com for further information about the Journal or to subscribe. 


\section{The Design Principles \& Practices Community}

This knowledge community is brought together by a shared interest in the process of design and their conceptual foundations. The community interacts through an innovative, annual face-to-face conference, as well as year-round virtual relationships in a weblog, peer reviewed journal and book imprint - exploring the affordances of the new digital media. Members of this knowledge community include academics, designers, administrators, educators, consultants and research students.

\section{Conference}

Members of the Design Community meet at the International Conference on Design Principles and Practices, held annually in different locations around the world. The Design Conference was held at Imperial College London, in 2007; in conjunction with the University of Miami, Florida, USA in 2008; at Technical University Berlin, Germany in 2009; at the University of Illinois at Chicago, USA in 2010; and at Sapienza University of Rome, Italy in 2011. In 2012, the conference will be held at the University of California, Los Angeles, USA.

Our community members and first time attendees come from all corners of the globe. Intellectually, our interests span the breadth of the field of design. The Conference is a site of critical reflection, both by leaders in the field and emerging scholars and practitioners. Those unable to attend the Conference may opt for virtual participation in which community members can either submit a video and/or slide presentation with voice-over, or simply submit a paper for peer review and possible publication in the Journal.

Online presentations can be viewed on YouTube.

\section{Publishing}

The Design Community enables members of its community to publish through three media. First, by participating in the Design Conference, community members can enter a world of journal publication unlike the traditional academic publishing forums - a result of the responsive, non-hierarchical and constructive nature of the peer review process. Design Principles and Practices: An International Journal provides a framework for double-blind peer review, enabling authors to publish into an academic journal of the highest standard.

The second publication medium is through the book series On Design, publishing cutting edge books in print and electronic formats. Publication proposals and manuscript submissions are welcome.

The third major publishing medium is our news blog, constantly publishing short news updates from the Design Community, as well as major developments in the field of design. You can also join this conversation at Facebook and Twitter or subscribe to our email Newsletter. 


\section{Common Ground Publishing Journals}

\begin{tabular}{|c|c|}
\hline $\begin{array}{l}\text { AGING } \\
\text { Aging and Society: An Interdisciplinary Journal } \\
\text { Website: http://AgingAndSociety.com/journal/ }\end{array}$ & $\begin{array}{c}\text { ARTS } \\
\text { The International Journal of the Arts in Society. } \\
\text { Website: www.Arts-Journal.com }\end{array}$ \\
\hline $\begin{array}{c}\text { BOOK } \\
\text { The International Journal of the Book } \\
\text { Website: www.Book-Journal.com }\end{array}$ & $\begin{array}{c}\text { CLIMATE CHANGE } \\
\text { The International Journal of Climate Change: } \\
\text { Impacts and Responses } \\
\text { Website: www.Climate-Journal.com }\end{array}$ \\
\hline $\begin{array}{c}\text { CONSTRUCTED ENVIRONMENT } \\
\text { The International Journal of the } \\
\text { Constructed Environment } \\
\text { Website: www.ConstructedEnvironment.com/journal }\end{array}$ & $\begin{array}{c}\text { DESIGN } \\
\text { Design Principles and Practices: } \\
\text { An International Journal } \\
\text { Website: www.Design-Journal.com }\end{array}$ \\
\hline $\begin{array}{c}\text { DIVERSITY } \\
\text { The International Journal of Diversity in } \\
\text { Organizations, Communities and Nations } \\
\text { Website: www.Diversity-Journal.com }\end{array}$ & $\begin{array}{l}\text { FOOD } \\
\text { Food Studies: An Interdisciplinary Journal } \\
\text { Website: http://Food-Studies.com/journal/ }\end{array}$ \\
\hline $\begin{array}{c}\text { GLOBAL STUDIES } \\
\text { The Global Studies Journal } \\
\text { Website: www.GlobalStudiesJournal.com }\end{array}$ & $\begin{array}{c}\text { HEALTH } \\
\text { The International Journal of Health, } \\
\text { Wellness and Society } \\
\text { Website: www.HealthandSociety.com/journal }\end{array}$ \\
\hline $\begin{array}{c}\text { HUMANITIES } \\
\text { The International Journal of the Humanities } \\
\text { Website: www.Humanities-Journal.com }\end{array}$ & $\begin{array}{c}\text { IMAGE } \\
\text { The International Journal of the Image } \\
\text { Website: www.Onthelmage.com/journal }\end{array}$ \\
\hline $\begin{array}{l}\text { LEARNING } \\
\text { The International Journal of Learning. } \\
\text { Website: www.Learning-Journal.com }\end{array}$ & $\begin{array}{c}\text { MANAGEMENT } \\
\text { The International Journal of Knowledge, } \\
\text { Culture and Change Management. } \\
\text { Website: www.Management-Journal.com }\end{array}$ \\
\hline $\begin{array}{c}\text { MUSEUM } \\
\text { The International Journal of the Inclusive Museum } \\
\text { Website: www.Museum-Journal.com }\end{array}$ & $\begin{array}{c}\text { RELIGION AND SPIRITUALITY } \\
\text { The International Journal of Religion and } \\
\text { Spirituality in Society } \\
\text { Website: www.Religion-Journal.com }\end{array}$ \\
\hline $\begin{array}{c}\text { SCIENCE IN SOCIETY } \\
\text { The International Journal of Science in Society } \\
\text { Website: www.ScienceinSocietyJournal.com }\end{array}$ & $\begin{array}{c}\text { SOCIAL SCIENCES } \\
\text { The International Journal of Interdisciplinary } \\
\text { Social Sciences } \\
\text { Website: www.SocialSciences-Journal.com }\end{array}$ \\
\hline $\begin{array}{c}\text { SPACES AND FLOWS } \\
\text { Spaces and Flows: An International Journal of } \\
\text { Urban and ExtraUrban Studies } \\
\text { Website: www.SpacesJournal.com }\end{array}$ & $\begin{array}{c}\text { SPORT AND SOCIETY } \\
\text { The International Journal of Sport and Society } \\
\text { Website: www.sportandsociety.com/journal }\end{array}$ \\
\hline $\begin{array}{c}\text { SUSTAINABILITY } \\
\text { The International Journal of Environmental, Cultural, } \\
\text { Economic and Social Sustainability } \\
\text { Website: www.Sustainability-Journal.com }\end{array}$ & $\begin{array}{c}\text { TECHNOLOGY } \\
\text { The International Journal of Technology, } \\
\text { Knowledge and Society } \\
\text { Website: www.Technology-Journal.com }\end{array}$ \\
\hline $\begin{array}{c}\text { UBIQUITOUS LEARNING } \\
\text { Ubiquitous Learning: An International Journal } \\
\text { Website: www.ubi-learn.com/journal/ }\end{array}$ & $\begin{array}{l}\text { UNIVERSITIES } \\
\text { Journal of the World Universities Forum } \\
\text { Website: www.Universities-Journal.com }\end{array}$ \\
\hline
\end{tabular}

